Review

\title{
Ecologies of Scale: Multifunctionality Connects Conservation and Agriculture across Fields, Farms, and Landscapes
}

\section{Devan Allen McGranahan}

Range Science Program, School of Natural Resource Sciences, North Dakota State University, Fargo, ND 58108-6050, USA; E-Mail: devan.mcgranahan@ndsu.edu; Tel.: +1-701-231-7868; Fax: +1-701-231-8557

Received: 16 May 2014; in revised form: 10 July 2014 / Accepted: 14 July 2014 /

Published: 18 July 2014

\begin{abstract}
Agroecology and landscape ecology are two land-use sciences based on ecological principles, but have historically focused on fine and broad spatial scales, respectively. As global demand for food strains current resources and threatens biodiversity conservation, concepts such as multifunctional landscapes and ecologically-analogous agroecosystems integrate ecological concepts across multiple spatial scales. This paper reviews ecological principles behind several concepts crucial to the reconciliation of food production and biodiversity conservation, including relationships between biodiversity and ecosystem functions such as productivity and stability; insect pest and pollinator management; integrated crop and livestock systems; countryside biogeography and heterogeneity-based rangeland management. Ecological principles are integrated across three spatial scales: fields, farms, and landscapes.
\end{abstract}

Keywords: agroecology; biodiversity conservation; dynamic cropping systems; integrated crop-livestock systems; landscape ecology; multifunctional landscapes; sustainable agriculture; sustainable landscape design

\section{Introduction}

In recent decades, two parallel fields of land-use science have developed around ecological principles: agroecology and landscape ecology. Preceded by environmental movements in the 1960s and 1970s, agroecology emerged by the 1990s as the science of "applying ecological concepts and principles to the design and management of sustainable food systems ([1], p.369)" and has developed to include a broad social movement incorporating rural reform [2,3]. Meanwhile landscape ecology 
emerged in the 1980s and 1990s as the explicit study of spatial patterns and ecological processes [4,5]. However, despite a shared foundation in ecology these disciplines consider different spatial scales and often different systems. As a science, agroecology has focused on fine resolutions of agricultural production such as the field and farm scales [2] while landscape ecology has historically focused on broad spatial scales mostly beyond the human-dominated matrix [6].

The multifunctional landscape concept provides a framework to not only integrate agroecology and landscape ecology across multiple spatial scales but also use them to reconcile otherwise competing land-use objectives such as agricultural production and biodiversity conservation. Multifunctional agriculture turns on the idea that farms and farmed landscapes can produce more than just food and fiber, but also valuable ecosystem services and non-commodity goods [7]. Ecosystem services connect landscape ecology and agroecology because agroecology scales up to the human food system but landscape ecology lacks the specific capacity to account for such human valuation [8].

This paper aims to give readers a general understanding of how ecological principles of biodiversity apply to agriculture and connect ecological patterns and processes with agricultural production at multiple spatial scales. Ecology has considerable insight into how biotic interactions can be manipulated in agroecosystems [9]. In this review, I highlight the contributions of agroecology and landscape ecology towards understanding ecological functions of biodiversity useful to land managers at three spatial scales: from the field or pasture, through farms and ranches, up to broad multifunctional landscapes. Farmers and ranchers worldwide can either drawn upon or provide many of these functions to enhance both agricultural production and biodiversity conservation.

\section{Understanding and Applying Multifunctionality}

\subsection{General Concepts}

At a general level, multifunctionality relies upon two understandings: (1) all potential land use can be sorted along a gradient of intensity; and (2) land varies in the intensity of use it can withstand. Ellis and Ramankutty [10], and Foley et al. [11] describe various land uses and their relative intensities, ranging from natural ecosystems to extensive grazing on rangeland and small-scale subsistence agriculture, to intensive commercial agriculture, to villages and dense urban settlements. Throughout human history, land use has intensified and natural ecosystems have been converted to some type of human-mediated land use, and increases in human population and economic globalization have increased the rate of conversion and degree of intensification [11-13]. As a consequence, land use intensification has been linked to loss of productivity, biodiversity declines, and depleted ecological function [14-18]. Today, more than $75 \%$ of Earth's terrestrial area has been reshaped into human-dominated biomes [10]. Such land use change is one of the strongest drivers of change affecting terrestrial biodiversity [19].

Meeting increased demand for agricultural products will require substantial land-use changes. Broadly speaking, agricultural production of both food and fuel must increase while the environmental footprint of agriculture decreases [20]. These seemingly contrary objectives will require more landscapes to provide multiple functions. In other words, ecosystems previously set aside as natural reserves for biodiversity might need to contribute more human-oriented functionality while agricultural 
areas will need to foster greater biodiversity. In the US, this perspective runs contrary to at least a century of categorical land use policy in which John Muir dominates one side of the fence, and John Deere the other. However, instead of sparing land for conservation as agriculture intensifies elsewhere, land uses can be shared in multifunctional landscapes [20-25]. An interdisciplinary approach to landscape design that targets ecological function, production, and social capital is an important step towards blurring lines between singular land use objectives [26-29].

From the perspective of sustainable development, decisions on landscape alteration must balance the impact on the land and take account of both intensity of use and capacity to withstand use. Indeed, the scientific multi-scale landscape design process begins with defining the site and its landscape context [26]. This echoes the "nature as measure" principle of place-based sustainable agriculture [30,31], in which the local ecology of land is given a degree of agency in determining appropriate products and methods for agricultural production, instead of relying upon costly modifications and inputs for products otherwise less suited to the site. In this sense, broad abiotic and biotic patterns such as climate, soil, hydrology and disturbance regimes immediately relate to land-use decision-making at fine spatial scales. The spatial extent of a landscape — and management parcels within it — depends upon the same factors of environmental variability. In this paper, landscape is used to encompass all landscape positions - uplands, slopes, and bottomlands - and other factors affecting spatial resource heterogeneity.

\subsection{Examples of Multifunctional Landscapes}

\subsubsection{Intensively-Farmed Landscapes in the US Corn Belt}

Specific examples of multifunctional landscapes are emerging from intensively-farmed regions such as the American Midwest. Settlers entering the region in the mid-19th century found deep, productive prairie soils and worked to convert vast areas of native prairie grassland to farmland. Small, diverse farms steadily gave rise to larger operations with less crop diversity, and today most agricultural production consists of maize, soybeans, and confined livestock feeding operations [32-37]. Concurrent with agricultural intensification has been sharp declines in soil and water quality and loss of natural habitat and biodiversity [38-41]. Meanwhile the landscape scale has generally been disregarded as a driver of short-term agricultural productivity, although recent work suggests landscape influences long-term ecosystem function [42]. Research is underway to apply multifunctionality as a simultaneous solution to environmental degradation, loss of wildlife and habitat, and socio-economic issues associated with low crop diversity in a globalized market $[29,43]$.

In intensively-farmed landscapes where the primary land-use is annual crops, the first step to mitigating negative aspects of agricultural production is likely increasing the amount of perennial vegetation on the landscape [44]. However, although voluntary government conservation programs that incentivize perennial vegetation have been popular, participation is often short-lived as row-crop prices increase $[37,45,46]$. From a multifunctional landscape perspective, converting intensively-managed cropland to set-aside conservation land - effectively "switching off" all agricultural production - might not be the most efficient use of land or best method to reduce negative impacts across the catchment. Instead, broad, coordinated landscape design can match land uses of various intensities - from conservation areas to extensively-managed rangeland to intensively-managed pasture 
and finally to cropland - to appropriate areas of the landscape that optimize output potential of food, fiber, and non-commodity ecosystem good and services. Several research efforts address how different proportions of real landscapes might be managed for such multifunctionality [7,43], while others describe how landowners and policy makers can facilitate such changes $[29,46,47]$.

\subsubsection{Commercial Conservancies in Southern African Rangeland}

Agricultural production also threatened the persistence of native biodiversity on commercial ranches in Southern Africa. For example, in former South-West Africa (now Namibia) in the 1960s, farmland was sold at a premium when native ungulates had been extirpated, thus reducing competition with domestic livestock for scarce forage and water resources [48,49]. In 1967, the government essentially launched a private game industry $[48,50]$ that increased wildlife populations on commercial farms $c a$. 70\% between 1972 and 1992 [51]. With a market incentive to manage wildlife populations alongside domestic livestock, these commercial rangelands became multifunctional landscapes that produce diverse agricultural output (meat and fiber from multiple domestic and wild species), create new markets (foreign trophy hunters and ecotourists), and conserve native biodiversity $[52,53]$.

Participation in cooperative management units known as conservancies can extend ecological and economic benefits of the wildlife industry for both private landowners and citizens of communally-controlled land in Southern Africa. By coordinating management decisions across multiple land holdings, conservancies can manage an even broader suite of native wildlife, including predators; defray management costs such as poacher control, brush removal, or prescribed fire; advertise for more tourists and hunters; and engage both local communities and traditional conservation areas [54,55]. Thus, conservancies represent an opportunity to scale up mutually-beneficial production and conservation practices and incorporate ecologically-analogous management regimes, consistent with broad efforts to to promote multifunctionality in Southern African landscapes [56,57].

\section{Ecological Concepts of Biodiversity}

Biological diversity — widely known as biodiversity — is a broad term with several definitions and applications that vary with context. Biodiversity can refer to several levels of organization, including functional diversity, species diversity, and genetic diversity. In each case, "diversity" typically refers to the degree of variability within each measure. Diversity can be high at one level of organization and low in another, as in a plant community with many species planted in one area, but limited genetic variability within each species perhaps because each species came from a plant breeder with narrow genetic lines within source populations.

\subsection{Species Richness}

Measuring diversity at any level of organization can be a difficult task, with results subject to the nature of the measurements taken. For example, one of the basic components of diversity is species richness, and is measured by simple species counts within a given area. However, species richness alone does not account for whether one or a few species dominate the stand-some species might occur at greater frequency or produce more biomass than other species. Thus, ecologists also consider 
the evenness of the stand an important element of diversity, and several popular equations combine both species richness and evenness into a single index of diversity.

Diversity measures are also confounded by spatial scale. When measuring species richness and/or evenness, the spatial bounds are arbitrary, and can include a sample plot, a field, a farm, or a watershed. Furthermore, different species might occur in different areas, due to either different management regimes or simply due to natural variability in soils, water, and other factors. As such, simply comparing diversity measures across different habitats might overlook important differences in species identity. Three terms address differences in species composition across space, although spatial resolutions must still be explicitly_ and perhaps arbitrarily—defined [58]:

- Alpha diversity - Species richness within a locally-defined spatial extent, or patch.

- Beta diversity - The degree of change, or turnover, of species among local patches. Patches with dissimilar species composition have high beta diversity, and vice versa, irrespective of alpha diversity within patches.

- Gamma diversity - Conceptually, represents species richness at the broadest spatial scale (landscape, region, continent, etc.). Mathematically, a combination of alpha and beta diversity at fine spatial scales.

\subsection{Functional and Response Diversity}

Perhaps more relevant to understanding the relationship between biodiversity and ecosystem processes is functional diversity [59]. Functional diversity refers to the extent of difference among types of species in a community; species of similar types are often referred to as functional groups and are differentiated by traits [60]. For example, a multivariate analysis of traits from 158 species in a native grassland community found eight distinct groups differentiated by photosynthetic pathway, growth form, season of growth, and nitrogen fixation [61]. When classified by meaningful traits, functional groups can be more convenient and more realistic units to study and manage plant communities, as opposed to species richness [62]. Functional diversity can even be parsed into spatial components and reported as alpha, beta, and gamma to determine the spatial pattern of trait overlap across a community and facilitate comparison across different areas [63].

Important to understanding functional diversity is response diversity, which refers to the range of reactions among species that perform the same ecological function [64]. Reduced response diversity might make an ecosystem more sensitive to disturbance and environmental change [65]. Response diversity appears to be related to species richness within functional groups [66], a phenomenon known as functional redundancy, in which several species of the same functional group respond uniquely to different environmental conditions [67].

Biodiversity is clearly related to ecosystem function, but in agricultural landscapes, different processes are relevant at different spatial scales (Table 1). Biodiversity contributes to agroecological production at fine spatial scales (fields, pastures, and within farm units) while multifunctional agricultural systems support biodiversity at broad spatial scales (among farms and landscapes). The sections below explore the relationships between biodiversity theory, agroecology, and landscape ecology at their relevant scales. 
Table 1. Summary of ecological principles and their agricultural applications at each of the spatial extents considered in this review.

\begin{tabular}{|c|c|c|}
\hline Spatial Extent & Relevant Ecological Principles & Agricultural Applications \\
\hline \multirow{3}{*}{ Field } & $\begin{array}{l}\text { Species richness } v s . \\
\text { functional diversity (alpha diversity) }\end{array}$ & $\begin{array}{l}\text { Composition of production stands: many } \\
\text { species, or many types? }\end{array}$ \\
\hline & $\begin{array}{l}\text { Diversity_productivity relationships: } \\
\text { selection effect (non-transgressive } \\
\text { overyielding) } v s . \text { complementarity } \\
\text { (transgressive overyielding) }\end{array}$ & $\begin{array}{l}\text { Farmers might target several } \\
\text { highly-productive species } \\
\text { with different functions. }\end{array}$ \\
\hline & Diversity enhances stability & $\begin{array}{l}\text { Mixed stands might show less } \\
\text { variability in function, especially } \\
\text { if climate becomes unpredictable. }\end{array}$ \\
\hline \multirow{2}{*}{ Farm } & \multirow{2}{*}{$\begin{array}{l}\text { Marginal vegetation, beta diversity, } \\
\text { and trophic complexity }\end{array}$} & $\begin{array}{l}\text { Increase habitat for associated } \\
\text { biodiversity, including beneficial } \\
\text { invertebrate predators and pollinators. }\end{array}$ \\
\hline & & $\begin{array}{l}\text { Integrating crops and livestock } \\
\text { increases product diversity, } \\
\text { adds value, and closes nutrient cycles. }\end{array}$ \\
\hline \multirow[t]{2}{*}{ Landscape } & $\begin{array}{l}\text { Countryside biogeography; } \\
\text { patch-matrix-corridor } \\
\text { concept vs. habitat contours }\end{array}$ & $\begin{array}{l}\text { Lower-quality areas as stepping } \\
\text { stones to connect high-quality habitat. }\end{array}$ \\
\hline & $\begin{array}{l}\text { Heterogeneity-based rangeland } \\
\text { management }\end{array}$ & $\begin{array}{l}\text { Ecologically-analogous disturbance } \\
\text { patterns reconcile livestock production, } \\
\text { biodiversity conservation. }\end{array}$ \\
\hline
\end{tabular}

\section{Agroecology: Biodiversity at Fine Spatial Scales}

Central question: How does biodiversity contribute to agricultural production at the field and farm scales?

\subsection{The Natural Ecosystem Analogy Concept}

Agroecosystems are ecosystems dominated by crops, domestic livestock, and human populations [68], and their design begins with replicating the structure, function, and flow of natural ecosystems. According to Altieri, "a main strategy in agroecology is to exploit the complementarities and synergism that result from various combinations of crops, trees, and animals ([69], p.22)." This recalls Hart's concept of natural ecosystem analogy: "the natural ecosystem can be exploited as an information source by applying ecological principles derived from natural plant associations to the crop-system design process, or by considering the natural ecosystem as a model for a crop system ([68], p. 73)."

Altieri describes several components of biodiversity specific to the structure and function of agroecosystems [69]. These include productive biota, which includes the crops, trees, and animals managed for agricultural products; resource biota, which provide services like pollination, pest control, and nutrient cycling; and destructive biota, the weeds, pests, and pathogens. All three categories can be described as either planned or associated diversity, depending on whether its inclusion was specifically intended by the farmer. In most cases, planned diversity relates to 
productive biota, and can be directly managed to mimic the structure of natural ecosystems; if managed properly, the functions of natural ecosystems will be mimicked, as well, with associated diversity supporting resource biota and reducing destructive biota. The ecological perspective-which I review below-draws heavily on biotic interactions to facilitate ecologically-analogous function in production systems [9].

\subsection{Does Diversity Enhance Ecosystem Function?}

Following decades of study, ecologists have connected biodiversity to several ecosystem functions and services [70-73], many of which are essential to the theory and practice of agroecology. Initially, researchers used simple measures of diversity such as species richness, but found that more complex concepts such as functional diversity explain the mechanisms behind the phenomena described [74]. The difference in approach is important because simple species counts offer little insight into the functional characteristics of individual species; with respect to agroecology, it is important to understand whether more species, generally, or species of certain types contribute to enhanced ecosystem function. Because different species affect different ecological functions, biodiversity is especially important in multifunctional systems [75].

Concepts of diversity can differ between natural and agricultural systems. Much of the literature reviewed below is ecological research, which seeks to determine the relationship between diversity and ecosystem function in nature. Diversity in agroecosystems might look different than in natural systems, but this ecological research is essential to understanding the mechanisms that drive the relationships managers seek to mimic in ecologically-analogous agroecosystems.

\subsubsection{Diversity and Productivity: Ecology of Mixed Stands}

A growing body of ecological research supports the hypothesis that communities with greater biodiversity are more productive than communities with less diversity [76]. While this link has clear implications in agroecology, the relationship between diversity and productivity is not straightforward. After early experimental research demonstrated a connection between increased species richness and primary productivity, the conversation among community ecologists turned to pit-falls in study design. Studies from the field [77,78] conflicted with data from plot-based experiments [79,80], prompting inquiry into "hidden treatments [81]" that arise from unseen consequences of experimental manipulation.

For example, scholars have debated the selection effect, in which combining species from a random pool increases the probability that a particularly highly-productive species is included in the stand; observed increases in biomass production can thus be attributed to a few specific species, and not simply to the number of species in the stand. Increased stand-level yield due to the selection effect is known as non-transgressive overyielding [82]. Some authors claim the effect is simply an artifact of experimental design and does not represent an actual ecological property [83], whereas others point out that any plant community represents some sub-set of the potential regional biota and the original experiments (e.g., [79]) represent an ecologically-valid effect of diversity [84,85]. Today, debate continues over whether diverse stands out-produce monocultures of their most productive species - known as transgressive overyielding [86,87]. This is a result of the complementarity effect [87], in which species benefit from positive interactions and/or resource-sharing that facilitates greater 
production and leads to overyielding. The complementarity effect is considered a more robust diversity mechanism and has received experimental support $[82,88,89]$.

Sensitive to the relative contributions of selection and complementarity effects, a new generation of diversity-productivity research seeks to partition out their relative contributions. However, selection effects linger. One meta-analyses concluded that "although productive species do indeed contribute to diversity effects, these contributions are equaled or exceeded by species complementarity ([90], p. 18123)," while another was less dismissive of selection effects: "there is presently little evidence to support the hypothesis that diverse polycultures out-perform their most efficient or productive species ([73], p. 581)."

Applied results are also inconsistent-both transgressive and non-transgressive overyielding are apparent in mixed-species cropping systems [89,91]. In the context of agroecosystems, though, it is important to consider the validity of non-transgressive overyielding because managers have the capacity to intentionally choose a mix of highly-productive species. Meanwhile, data from outside of crop fields suggests biodiversity restoration increases productivity of some grasslands [92,93], but not others [94]. Because these responses might correlate with a gradient of previous land-use intensity, it is likely that variability in productivity responses to diversity in agroecosystems might well be explained by a combination of intensity of previous management disturbance and time of recovery [95]. Indeed, complementarity effects have been shown to increase over time in polyculture crop systems [89].

\subsubsection{Multiple-Crop Systems: Diversity over Time}

Despite their similarity to natural ecosystems, mixed-species stands are currently limited to pasture and hay stands and not well integrated into commercial cropping systems (although some examples of cereal-legume intercropping exist (e.g., [96])). However, multiple-crop systems in which single-species crop stands are managed in succession within - and across - growing seasons represent a form of crop diversity in time if not space. From a production perspective, the financial argument for one, maximally-productive crop per season is clear, and farm management practice and policy in the US and abroad has - historically and/or currently_emphasized input-intensive, productionist systems often characterized by monocultures of annual crops or plantations [97-101]. Given environmental and market concerns, however, there is growing interest to develop multiple-crop systems that address pollution, including soil erosion and leaking of chemical inputs from the crop system; bolster resilience in the face of uncertain global environmental change; and enhance adaptability to changing demand for agricultural markets, such as biofuel production [102].

Multiple-crop systems seek to balance two goals: agricultural production and retention of soil and nutrients. Although single-crop productivity can be similar to the most diverse natural systems-for example, maize (Zea mays) in the US Corn Belt can produce $2.5-3.0 \mathrm{~kg} / \mathrm{m}^{2}$ of total biomass [103], compared to $3.4-3.7 \mathrm{~kg} / \mathrm{m}^{2}$ from native tallgrass prairie [104] — such maize fields are left with minimal to no ground cover for much of the year, leaving them susceptible to soil erosion and/or nutrient leaching [105]. Multi-crop systems seek to introduce additional crops that not only act as ground cover but also serve agricultural purposes, although the purposes of these other crops might not be the same as primary crops. For example, while primary commodity or feed crops such as maize, cereals, 
and grain soybeans (Glycine max) might dominate the growing season, cover crops are managed before and after the growing season.

Cover crops can provide a range of ecosystem goods and services. Cover crops might be used for fodder, either as hay/pasture in subsequent seasons or simply as an emergency grazing reserve; harvested for biofuel production; turned over as green manure (e.g., low-growing leguminous forbs such as Trifolium clovers); or develop into a commodity crop in the following season (e.g., winter wheat Triticum aestivum). There is even evidence that cover crops and crop residue can benefit small mammals that forage on agricultural weeds; these animals can range wider in search of food under sufficient vegetative cover [106,107].

A growing body of research from Iowa State University's Marsden Farm highlights the economic and environmental benefits of multiple-crop systems. The experiment tests conventional agriculture - characterized by simple crop rotations and heavy reliance on external inputs derived from fossil fuels - against low-external-input alternatives comprised of diverse crop rotations [108]. The diverse, low-input systems (comprised of maize, soybean, small grains and a leguminous cover crop) are competitive with conventional systems (maize and soybean) in terms of crop production and economic performance [109,110]. The diverse crop rotations-which rely on manure for fertilizer - also reduce fossil energy consumption and water pollution [111,112].

While the productivity of any species, in terms of biomass, do not approach that of the maximum of a single crop such as maize, near-perennial land cover mimics an ecosystem service of natural ecosystems and in some cases, when summed over the entire season, production of all crops in the multi-crop system might exceed biomass production of the single crop [113]. Under current practices, perennial crop cover requires the successive planting and harvesting of annual crops, although plant breeders are developing perennial cereals and grains [114-116]. For sites where the natural ecosystem consists of diverse grassland, the Holy Grail of ecologically-analogous agroecosystems is a perennial polyculture of forage- and grain-producing plants. Although the logistical questions of breeding, maintaining, and harvesting such a system are unlike most others addressed by either crop scientists or ecologists, attempts are being made [117].

\subsubsection{Diversity-Stability Relationships}

In addition to increasing production, conventional ecological wisdom also holds that biodiversity stabilizes productivity through time [90,118,119]. Although science has several definitions of stability, stability in productivity can best be described as a form of constancy, in which the ecosystem function remains unchanged-i.e., has low variability - through time or across space [118,120-122]. Stability through diversity has been referred to as a portfolio effect: like a well-hedged stock portfolio, primary production at the community level is more constant when variability in the performance of individual members is averaged out across the community [123-125].

Support for the diversity-stability hypothesis has taken a similar arc as research on diversity and productivity relationships, beginning with simple measures of diversity such as species richness [126,127] and expanding to evenness [123,125] and functional diversity [128,129]. The portfolio effect is also attributed to both statistical and ecological mechanisms [124]. Functional redundancy is one ecological mechanism [130,131]; for example, a pasture stand with several grasses might have a diversity of 
tolerance for wet soil and drought, so no matter the rainfall patterns of a given year, at least one species in the stand should flourish. Indeed, complex species mixtures are recommended to reduce variability in pasture production created by variation in precipitation [132].

As study systems and field applications become more complex, the relationship between diversity and stability depends more on environmental context. In the real world, two community properties are especially important determinants of the portfolio effect: species synchrony and community evenness. Synchrony-or its reciprocal, asynchrony-refers to how different species respond to different environmental conditions at different times; for example, when peak productivity varies from species to species throughout a growing season, total community productivity remains high even as individual productivity fluctuates [133]. Interestingly, evidence suggests that asynchrony is greatest and community biomass production most stable in mixed stands with different functional groups [134]. Evenness, meanwhile, has both direct and indirect effects on stability: direct because theory explicitly predicts reduced portfolio effects, and indirect because lower evenness can reduce species richness, with knock-on effects on stability [135-137].

Especially relevant to agricultural managers is the confounding effect of fertilization and dominant species on diversity-stability relationships. While agricultural grasslands-especially native plant communities - are typically managed less intensively than crop systems, these are potential sources of biofuel feedstock, and fertilizer increases both quantity and quality of native grasses used in biofuel production [138]. However, adding nutrients to mixed stands of native plants has been shown to increase competition for resources during critical points in the growing season, whereas unfertilized mixtures demonstrated complementarity [139], which suggests reduced synchrony/stability effects. Meanwhile, some studies report that grassland diversity and stability increase following fertilization [140-142], while other research shows increased stability despite decreased diversity due to increased dominance by a few stable species [143]. In the field, dominant species can show above-average stability independent of species richness [134,144]. Similar to a selection effect, the role of dominant species explains cases when pasture productivity is greater in mixed-species stands than monocultures but does not increase with richness [145], or species identity is more important than overall species richness [146].

\subsection{Diversity at the Farm Scale}

Many agroecological pest and livestock management practices require a farm-scale approach. For pests, some resources, such as habitat for beneficial insects and invertebrate predators, occur beyond the crop field. Rotating crops among fields in different seasons can also reduce pressure from many soil-borne pests, and an important element of crop rotations is pasture and fodder production for livestock. Integrating crop and livestock management can add value to each enterprise because they supplement each other: crops as livestock feed and animal waste as crop fertilizer. In addition, associated biodiversity can also benefit from a variety of habitats such as woodlots, hedgerows, and orchards interspersed among pastures and fields [147]. Thus, farm-level diversity is an exercise in beta diversity in which ecology and productivity go both ways: biodiversity can support agricultural production, and agricultural management can enhance biodiversity by creating a variety of habitat types. 


\subsubsection{Insect Management: Preventing Pests and Bolstering Beneficial Bugs}

While many producers seek non-chemical solutions to pest control, agroecologists specifically apply ecological solutions rather than simply substitute inputs [148,149]. An important first step in pest management is reversing the trend toward simplified production systems [150], which lack the ecological relationships found in more complex communities and allow exploitation by "weedy" plants and invertebrates. With its focus on production-oriented traits, even the very process of crop domestication might disrupt relationships between plants and pests [151]. While landscape complexity seems likely to promote both pollinators and natural enemies of agricultural pests, more research is necessary to determine the complexity of interactions within complex landscapes $[152,153]$.

Complex agroecosystems can provide habitat for natural predators of agricultural pests and prevent access to resources that pests need to establish populations [154,155]. Beetles, especially carabid beetles, are known to prey upon a variety of agricultural pests, and they are enhanced by crop diversity, minimal soil disturbance, and complex, vegetated field margins [156-158]. Spiders are another class of predators in agricultural systems that benefit from crop diversification and ground cover $[159,160]$.

Importantly, these same practices often support other beneficial invertebrate populations, including soil microbes and pollinators, but farmers often do not implement conservation practices on otherwise arable land because benefits are obscure or poorly understood [161]. Thus, farmers must see for themselves the benefits of both planned and unplanned diversity at the farm level, or receive financial incentives from biodiversity conservation programs, often from governments.

Many producers are familiar with Integrated Pest Management (IPM), which seeks to control pest populations with an ecosystem approach to environmental and population management, although IPM also incorporates chemical treatments [162]. While obviously not an option for purely organic producers, IPM represents a fairly mainstream application of ecological principles in agricultural pest management. Since its introduction in the mid-20th century, several IPM success stories have emerged from agricultural communities that embraced IPM culturally and logistically to reduce chemical pesticide applications $[163,164]$. The cultural aspect is important because ecological management of pest populations requires a broad-scale approach that often scales across fields and up to the landscape level, involving several management units.

Ecological pest management seeks a stable balance between pests and the invertebrate predators that prey upon pests. This balance can be achieved by maintaining habitat for predators and ensuring that the spatial arrangement of predator habitat allows access to the whole range where insect pests might occur, although outcomes are context-dependent and vary across spatial scales even within complex agricultural landscapes [165]. In fact, ecological research on natural predator-agricultural pest interactions suggest biological control might only be effective in heterogeneous systems [166].

Pollinators are an essential class of insects that benefit from complex vegetation. Through habitat loss and fragmentation, agricultural intensification has substantially reduced global pollinator populations [167,168]. However, not only can patches of vegetation in and between fields increase pollinator activity even in intensively-farmed areas $[169,170]$, proximity to such "marginal complexity" can boost yield of some insect-pollinated crops [171]. While many studies discuss distance from natural vegetation driving effective pollinator visitation [172], other research has shown 
that intentionally planting native vegetation strips-especially plant communities rich in wildflowers - provides a substantial boost to the habitat quality of the agricultural matrix [173-175]. Such vegetation could obviously be further integrated into multifunctional landscapes through ecologically-analogous disturbance patterns that combines livestock production and wildlife habitat management beneficial to pollinators [176].

\subsubsection{Integrating Crops and Livestock}

Integrated crop-livestock systems are an emphasis of agricultural research, as food production has become specialized and attention turns to agriculture's environmental footprint. Although specialized farms are highly productive, they also create the dual problem of excessive nutrient accumulation around confined animal feeding operations while cash crop farms import synthetic fertilizers $[177,178]$. Such a decoupled, open nutrient cycle deviates from both traditional farming systems - in which farms produced pasture and forage for livestock and returned nutrients to fields as manure-and natural ecosystems, in which herbivores cycle nutrients through complex trophic webs.

In addition to increasing productivity and stability within the plant community, biodiversity also contributes to ecosystem function in trophically-complex systems. Such "two-dimensional" biodiversity is vertically complex, with multiple levels of consumers feeding on primary producers, and functional redundancy (horizontal complexity) at each level [179]. Early comparison of energy flow through agricultural vs. natural systems noted that while natural systems have biomass concentrated at the bottom of the trophic structure-because energy naturally dissipates via entropy and metabolism as it moves up trophic levels - farm-level energy flow becomes increasingly "top-heavy" as farmers rely upon imported forage for livestock [180].

Integrating crops and livestock within or among farms is an important step towards local, closed nutrient cycles [181]. Integrating crops and livestock requires a whole-farm approach, including cover crops and emissions-reducing farm technology such as barns, manure storage and application $[181,182]$. Certainly nitrogen is important (e.g., [183]) but focusing on nitrogen alone risks nutrient imbalances; thus the entire nutrient cycle must be managed at a farm level [184]. For example, a farmer might manage livestock rations with soil quality in mind, as manure applications can increase soil concentrations of some heavy metals [185].

Multiple tradeoffs constrain the livestock industry in a changing global environment, but successfully balancing growth in demand for animal products against potential ecosystem services of livestock production will contribute to the sustainable integration of livestock into multifunctional landscapes [186]. Legitimate concerns about livestock production include greenhouse gas emissions, water use, and land conversion and degradation [187-191]. However, research suggests that, as a whole, the livestock industry has improved feed-use efficiency over recent decades [192,193], and new production practices and shifts in meat demand can reduce environmental impacts and perhaps even reduce global agricultural land area [194,195]. Livestock might contribute to "re-greening" land in multifunctional landscapes by facilitating agricultural production on land and in plant communities otherwise inaccessible to humans [196].

Unfortunately there is little incentive to incorporate livestock into crop-only farms [178], at least until policy emphasizes multifunctionality. In response to changes in the agricultural industry, 
however, some farmers are seeking to diversify their operations but state agencies have struggled to understand these dynamics well enough to target and support potential diversifiers [197]. While integrating a livestock component adds an obvious revenue stream, the option to sell other animal products such as fiber and dairy, or feed farm-produced crops as fodder instead of selling to the cash market, afford farmers market flexibility and opportunity to add value to raw agricultural products.

\section{Landscape Ecology: Ecological Diversity at Broad Spatial Scales}

Central question: How can the design of agricultural systems contribute to biodiversity conservation at the farm and landscape scales?

\subsection{Principles of Landscape Ecology}

Although spatial scales larger than individual farm units have rarely been considered in conventional agricultural studies, a landscape perspective is essential to promote multifunctionality. Just as farm-level biodiversity is both supported by and benefits from high functional beta diversity-i.e., a high degree of variability in land-use types as habitat for both planned and associated diversity - agricultural landscapes can support biodiversity by providing a variety of different habitats. Unfortunately the spatial scales of ecological processes, conservation, and agricultural management have typically been mismatched [198,199], but the multifunctional landscape paradigm, based on ecological structure, function, might improve the contribution of production landscapes to biodiversity conservation [26].

As a science, landscape ecology is the study of spatial patterns in ecological processes [200]. Landscape ecology addresses heterogeneity and complexity across spatial scales [201], which extends several agroecological principles from fields and farms to agricultural landscapes. In addition, although landscape ecology has generally focused on landscapes beyond the human-dominated matrix [6], recent scholarship extends landscape ecology to the design of multifunctional landscapes that include biodiversity conservation and anthropogenic land use [8,201-206].

Two concepts of landscape ecology - the patch and the landscape matrix - inform how patterns are described within and across spatial scales. A patch is generally described as a discrete surface area meaningfully different from its surroundings, and the degree of difference among patches referred to as patch contrast [207]. Patch structure can be hierarchical, with varying degrees of contrast among patches at different spatial scales [208]. Patches are often organism-specific, with different organisms identifying patches and resolving contrast among them at different spatial scales. The concept of contrast implies a degree of homogeneity within patches - regardless of their spatial extent — such that differences between patches creates heterogeneity among patches at higher spatial hierarchies (e.g., [209,210]).

The matrix accounts for areas of the landscape that are not considered habitat-gaps between patches. The concept originates from island biogeography theory, which describes population dynamics of islands of varying distance from mainland populations [211]. Applied to terrestrial organisms, island biogeography theory assumes habitats are discrete and the matrix - open water-is inhospitable. Coupled with the land-sparing ethic of John Muir on one side of the fence and John Deere on the other, island biogeography theory regards conservation areas as islands of habitat in an inhospitable matrix of agricultural land. However, a land-sharing, multifunctional perspective blurs the 
distinction between habitat and the matrix, and value becomes complex: patch sizes and relative quality are species-specific and temporally variable.

\subsection{Countryside Biogeography}

Countryside biogeography applies concepts of island biogeography theory to landscapes with variable matrix properties. This approach assumes a matrix of variable-rather than wholly inhospitable - habitat types and explores effective isolation not simply by distance from other patches, but also by the relative usefulness of the matrix to organisms moving between patches [212]. Experimental evidence indicates that patches of lower-but-tolerable quality habitat can act as stepping stones between high-quality patches within a matrix of, for instance, high-intensity land use [213]. So while an organism might not be able to complete its entire life cycle in the lower-quality habitats, such patches might be sufficient to, say, feed or rest while moving between high-quality areas.

Countryside biogeography has at least three major implications for the design of agricultural landscapes: (1) From a production standpoint, low-intensity land uses (haying, grazing, fallow fields) can support biodiversity and function as connector habitat between conservation reserves; (2) Conservation reserves are no longer genetically isolated from each other and might even be spaced more widely given that new habitat types allow connectivity; and (3) Conservation areas might be under less pressure to provide every last resource need for all species, as some resources might be found out in the less-inhospitable matrix.

Connectivity between patches is a complex issue because species differ in their ability to move between patches, which affects organismal tolerance for matrix habitat and acceptable distance between patches. To facilitate effective conservation of the maximal amount of biodiversity, the pattern and processes of all patch types should be managed to increase their value as both primary and secondary habitat for a wide variety of species [214]. Habitat contour models have been proposed as an alternative to patch-matrix-corridor models to account for context-dependent and species-specific complexity [215]. By assigning a layer to each species, habitat contour models accommodate species-specific differences in habitat quality over space and differences in spatial resolution among species. Collectively, the layers identify peak areas of conservation value and elucidate spatial patterns of connectivity and edge contrasts. Such ecological models can then be combined with social behavioral models to identify farmers most likely to manage fields and farms in a manner compatible with landscape-level objectives [216].

\subsection{Heterogeneity-Based Rangeland Management}

Rangeland ecosystems are inherently heterogeneous in which patterns of nutrient variability, rainfall, and productivity drive ecological processes such as herbivory and nutrient cycling [217-220]. For years production-oriented managers have sought to reduce heterogeneity or overcome it through intensive management practices such as rotational grazing systems that emphasize homogeneous forage utilization across heterogeneous landscapes [221]. However, upon observing population declines in wildlife that depend upon habitat types not created-or actively managed against - in production-oriented, homogeneity-based grazing schemes, rangeland ecologists call for ecologically-analogous, heterogeneity-based management [222]. 
Many grasslands around the world evolved under the interactive effects of fire and grazing. Wildfires, a natural component of many natural grassland ecosystems, burn away accumulated biomass and concentrate large herds of grazers to burned areas, drawn by the high nutritional content of succulent post-fire regrowth [223,224]. Meanwhile, other areas of the landscape with lower forage quality continue to accumulate plant biomass, increasing their probability of burning under future ignitions and drawing grazers across the landscape in a shifting spatio-temporal mosaic [225]. Wildlife communities respond to the heterogeneous landscape of internally-homogeneous habitat patches, increasing landscape-level biodiversity above that found in conventionally-managed, homogeneous rangeland [226-229].

The fire-grazing interaction can be mimicked in agricultural rangelands via patch burn-grazing management. Each year, managers apply prescribed fire to discrete patches, burning a different patch each year to ensure adequate fuel and create a shifting mosaic at the pasture or ranch level [230,231]. When managed correctly, contrast between patches is high and promotes heterogeneity in keystone structures for wildlife habitat [232,233]. Pastures, ranches, and grazed landscapes combine to create homogeneous patches across heterogeneous mosaics to promote biodiversity in working rangeland [234].

Thus, patch burn-grazing is an ecologically-analogous approach to agroecosystem management that simultaneously represents a shift towards a conservation paradigm focused on ecological pattern and process [235]. By mimicking ecological patterns at several spatial scales, patch burn-grazing advances both conservation goals and agricultural production-when grazing, an ecological process, follows the spatio-temporal pattern of fire, grazing by domestic cattle offers a similar conservation value as native ungulates [236,237]. At the same time, livestock production on patch burn-grazed rangeland is competitive with conventionally-managed rangeland [238], and evidence suggests patch burn-grazing even helps control livestock parasites [239].

Heterogeneity-based management might also contribute to enhanced resilience of agricultural productivity, which is especially important in an era of global environmental change. Functional diversity of rangeland resources - essentially beta diversity among landscape patches - is known to facilitate and even moderate herbivore populations across wet and dry seasons [240,241]. Spatial heterogeneity in forage resources also buffers livestock production against declines during dry periods [242], likely by ensuring emergency forage (a grass bank) in unburned areas if forage production in the burned patch declines [243]. It is likely that functional diversity among patches in a heterogeneously-managed landscape creates a portfolio effect at the landscape level, but both theoretical and empirical evidence is forthcoming.

\subsection{Biofuels and the Future of Agricultural Landscapes}

An open question for agricultural landscapes is whether lignocellulosic biofuel production will hinder or enhance multifunctionality [244]. On one hand, increasing the offtake of crop residues - which would otherwise be worked into the soil as organic matter-will likely exacerbate soil degradation [245]. However, on the other hand, an emphasis on native, perennial plants would not only constitute a radical shift from annual crops in US farm policy [45] but also create market incentive for perennial vegetation and potentially benefit wildlife [246,247]. Yet again, even with 
native plant systems, a production-oriented mindset on one or very few commodity products is likely detrimental to product diversity, non-commodity goods and services, and ecological integrity [248].

Rather than broad conversion of cropping systems for biofuels, biofuels should be seen as a complementary market for producers and crops meant specifically for cellulosic biofuel should be worked into the existing matrix of agricultural landscapes [249-251]. Iowa State University's Comparison of Biofuel Systems (COBS) experiment addresses tradeoffs between maize- and native vegetation-based biofuels systems [108]. Although maize-based systems have the greatest biomass productivity, such yields are dependent on much more nutrient input than even fertilized prairie [252]. Native prairie biomass systems also moderate subsurface water flow [253], an important ecosystem service related to flood prevention and nutrient runoff.

Especially when highly-erodible land is targeted, converting even small proportions of annual crop fields to perennial vegetation can have disproportionate ecosystem benefits and positive financial returns [254,255]. The Science-based Trials of Row-crops Integrated with Prairies (STRIPs) experiment at the Neal Smith Wildlife Refuge - a landscape-level prairie restoration effort in central Iowa, USA [256] — varies the proportion of crop and native vegetation cover between zero and $100 \%$ in different configurations to demonstrate how strategic placement of native vegetation in highly-productive cultivated landscapes enhance environmental quality [108]. While all levels of prairie buffers in various configurations reduced nutrient loss during runoff events, positioning even just $10 \%$ prairie cover at the bottom of cropped slopes had a disproportionate contribution to runoff reduction relative to the area planted to native vegetation [257,258]. Buffer plantings maintained consistent plant species diversity across buffer areas and configurations without increasing weed abundance in surrounding crop fields [259]. In addition, finally, native prairie buffer strips created habitat for grassland birds [174] in an otherwise inhospitable agricultural matrix.

\section{Conclusions}

Reconciling agricultural production with environmental protection and biodiversity conservation is one of humanity's greatest challenges [260], and will only increase as global environmental change accelerates and a growing human population demands more food, especially meat. The ecological literature has much to offer towards understanding how food production systems might operate analogously to natural ecosystems. By integrating agroecology and landscape ecology, multifunctional landscapes can be designed and managed such that food production is not only sustainable in terms of its own impact on natural resources, but that agricultural landscapes contribute to the conservation of biodiversity worldwide. Integration across scales might also resolve economic complications that arise from landscape-level benefits arising from farm-level practices [261].

An important conclusion from this review is that increasing the conservation and environmental protection value of agriculture does not demand a complete rejection of modern agricultural technologies. As demonstrated by the Marsden Farm trials, STRIPS, COBS, and the success of Integrated Pest Management, an ecological approach to agriculture can reduce the use of fossil fuel-derived inputs, maintain productivity and profitability, and contribute to social wellbeing and environmental quality. Looking forward, agricultural research must draw from community ecology and landscape ecology to develop further applications of ecological principles to other agricultural systems. 


\section{Conflicts of Interest}

The author declares no conflict of interest.

\section{References}

1. Gliessman, S.R. Agroecology: The Ecology of Sustainable Food Systems; CRC Press: Boca Raton, FL, USA, 2007.

2. Wezel, A.; Soldat, V. A quantitative and qualitative historical analysis of the scientific discipline of agroecology. Int. J. Agric. Sustain. 2009, 7, 3-18.

3. Altieri, M.A. Agroecology: A new research and development paradigm for world agriculture. Agric. Ecosyst. Environ. 1989, 27, 37-46.

4. Urban, D.L.; O’Neill, R.V.; Shugart, H.H., Jr. Landscape ecology. BioScience 1987, 37, 119-127.

5. Turner, M.G. Landscape ecology: The effect of pattern on process. Annu. Rev. Ecol. Syst. 1989, 20, 171-197.

6. Andersen, B.J. Research in the journal Landscape Ecology, 1987-2005. Landsc. Ecol. 2008, 23, 129-134.

7. Boody, G.; Vondracek, B.; Andow, D.A.; Krinke, M.; Westra, J.; Zimmerman, J.; Welle, P. Multifunctional agriculture in the United States. BioScience 2005, 55, 27-38.

8. Termorshuizen, J.W.; Opdam, P. Landscape services as a bridge between landscape ecology and sustainable development. Landsc. Ecol. 2009, 24, 1037-1052.

9. Shennan, C. Biotic interactions, ecological knowledge and agriculture. Philos. Trans. R. Soc. B Biol. Sci. 2008, 363, 717-739.

10. Ellis, E.C.; Ramankutty, N. Putting people in the map: Anthropogenic biomes of the world. Front. Ecol. Environ. 2008, 6, 439-447.

11. Foley, J.A.; Defries, R.; Asner, G.P.; Barford, C.; Bonan, G.; Carpenter, S.R.; Chapin, F.S.; Coe, M.T.; Daily, G.C.; Gibbs, H.K.; et al. Global consequences of land use. Science 2005, 309, 570-574.

12. DeFries, R.S.; Foley, J.A.; Asner, G.P. Land-use choices: Balancing human needs and ecosystem function. Front. Ecol. Environ. 2004, 2, 249-257.

13. Lambin, E.F.; Turner, B.L.; Geist, H.J.; Agbola, S.B.; Angelsen, A.; Bruce, J.W.; Coomes, O.T.; Dirzo, R.; Fischer, G.; Folke, C. The causes of land-use and land-cover change: Moving beyond the myths. Glob. Environ. Chang. 2001, 11, 261-269.

14. Laliberte, E.; Wells, J.A.; DeClerck, F.; Metcalfe, D.J.; Catterall, C.P.; Queiroz, C.; Aubin, I.; Bonser, S.P.; Ding, Y.; Fraterrigo, J.M.; et al. Land-use intensification reduces functional redundancy and response diversity in plant communities. Ecol. Lett. 2010, 13, 76-86.

15. Flynn, D.F.B.; Gogol-Prokurat, M.; Nogeire, T.; Molinari, N.; Richers, B.T.; Lin, B.B.; Simpson, N.; Mayfield, M.M.; DeClerck, F. Loss of functional diversity under land use intensification across multiple taxa. Ecol. Lett. 2009, 12, 22-33.

16. Reidsma, P.; Tekelenburg, T.; Vandenberg, M.; Alkemade, R. Impacts of land-use change on biodiversity: An assessment of agricultural biodiversity in the European Union. Agric. Ecosyst. Environ. 2006, 114, 86-102. 
17. Verón, S.R.; Paruelo, J.M.; Oesterheld, M. Grazing-induced losses of biodiversity affect the transpiration of an arid ecosystem. Oecologia 2011, 165, 501-510.

18. Milton, S.J.; Dean, W.R.J.; du Plessis, M.; Siegfried, W.R. A conceptual model of arid rangeland degradation. BioScience 1994, 44, 70-76.

19. Sala, O.E.; Chapin, F.S.; Armesto, J.J.; Berlow, E.; Bloomfield, J.; Dirzo, R.; Huber-Sanwald, E.; Huenneke, L.F.; Jackson, R.B.; Kinzig, A. Global biodiversity scenarios for the year 2100. Science 2000, 287, 1770-1774.

20. Foley, J.A.; Ramankutty, N.; Brauman, K.A.; Cassidy, E.S.; Gerber, J.S.; Johnston, M.; Mueller, N.D.; O'Connell, C.; Ray, D.K.; West, P.C.; et al. Solutions for a cultivated planet. Nature 2011, 478, 337-342.

21. Vandermeer, J.; Perfecto, I. The agricultural matrix and a future paradigm for conservation. Conserv. Biol. 2007, 21, 274-277.

22. Perfecto, I.; Vandermeer, J. The agroecological matrix as alternative to the land-sparing/agriculture intensification model. Proc. Natl. Acad. Sci. USA 2010, 107, 5786-5791.

23. Phalan, B.; Onial, M.; Balmford, A.; Green, R.E. Reconciling food production and biodiversity conservation: Land sharing and land sparing compared. Science 2011, 333, 1289-1291.

24. Egan, J.F.; Mortensen, D.A. A comparison of land-sharing and land-sparing strategies for plant richness conservation in agricultural landscapes. Ecol. Appl. 2012, 22, 459-471.

25. Phalan, B.; Balmford, A.; Green, R.E.; Scharlemann, J.P.W. Minimizing the harm to biodiversity of producing more food globally. Food Policy 2011, 36, S62-S71.

26. Lovell, S.T.; Johnston, D.M. Creating multifunctional landscapes: How can the field of ecology inform the design of the landscape? Front. Ecol. Environ. 2009, 7, 212-220.

27. Chazdon, R.L.; Harvey, C.A.; Komar, O.; Griffith, D.M.; Ferguson, B.G.; Martínez-Ramos, M.; Morales, H.; Nigh, R.; Soto-Pinto, L.; van Breugel, M.; et al. Beyond reserves: A research agenda for conserving biodiversity in human-modified tropical landscapes. Biotropica 2009, $41,142-153$.

28. O'Farrell, P.J.; Anderson, P.M. Sustainable multifunctional landscapes: A review to implementation. Curr. Opin. Environ. Sustain. 2010, 2, 59-65.

29. Atwell, R.C.; Schulte, L.A.; Westphal, L.M. How to build multifunctional agricultural landscapes in the U.S. Corn Belt: Add perennials and partnerships. Land Use Policy 2010, 27, 1082-1090.

30. Berry, W. Nature as measure. In What Are People For? Counterpoint: Berkeley, CA, USA, 1990; pp. 204-210.

31. Jackson, W.; Bormann, F.; Kellert, S. Nature as the measure for a sustainable agriculture. In Ecology, Economics, Ethics: The Broken Circle; Yale University Press: New Haven, CT, USA, 1991; pp. 43-58.

32. Hiller, T.L.; Powell, L.A.; McCoy, T.D.; Lusk, J.J. Long-term agricultural land-use trends in Nebraska, 1866-2007. Gt. Plains Res. 2009, 19, 225-37.

33. Wright, C.K.; Wimberly, M.C. Recent land use change in the Western Corn Belt threatens grasslands and wetlands. Proc. Natl. Acad. Sci. USA 2013, 110, 4134-4139.

34. Johnston, C.A. Agricultural expansion: Land use shell game in the U.S. Northern Plains. Landsc. Ecol. 2014, 29, 81-95. 
35. Dimitri, C.; Effland, A.B.W.; Conklin, N.C. The 20th Century Transformation of US Agriculture and Farm Policy; US Department of Agriculture, Economic Research Service: Washington, DC, USA, 2005.

36. Brown, P.W.; Schulte, L.A. Agricultural landscape change (1937-2002) in three townships in Iowa, USA. Landsc. Urban Plan. 2011, 100, 202-212.

37. McGranahan, D.A.; Brown, P.W.; Schulte, L.A.; Tyndall, J.C. Associating conservation/production patterns in U.S. farm policy with agricultural land-use in three Iowa, USA townships, 1933-2002. Land Use Policy 2014, in press.

38. Murphy, M.T.; Moore, F. Avian population trends within the evolving agricultural landscape of eastern and central United States. Auk 2003, 120, 20-34.

39. Broussard, W.; Turner, R.E. A century of changing land-use and water-quality relationships in the continental US. Front. Ecol. Environ. 2009, 7, 302-307.

40. Culman, S.W.; DuPont, S.T.; Glover, J.D.; Buckley, D.H.; Fick, G.W.; Ferris, H.; Crews, T.E. Long-term impacts of high-input annual cropping and unfertilized perennial grass production on soil properties and belowground food webs in Kansas, USA. Agric. Ecosyst. Environ. 2010, 137, 13-24.

41. Heathcote, A.J.; Filstrup, C.T.; Downing, J.A. Watershed sediment losses to lakes accelerating despite agricultural soil conservation efforts. PLoS One 2013, 8, e53554.

42. Wilson, D.M.; Heaton, E.A.; Schulte, L.A.; Gunther, T.P.; Shea, M.E.; Hall, R.B.; Headlee, W.L.; Moore, K.J.; Boersma, N.N. Establishment and short-term productivity of annual and perennial bioenergy crops across a landscape gradient. BioEnergy Res. 2014, doi:10.1007/s12155-014-9409-9.

43. Jordan, N.; Warner, K.D. Enhancing the multifunctionality of US agriculture. BioScience 2010, 60, 60-66.

44. Asbjornsen, H.; Hernandez-Santana, V.; Liebman, M.; Bayala, J.; Chen, J.; Helmers, M.J.; Ong, C.K.; Schulte, L.A. Targeting perennial vegetation in agricultural landscapes for enhancing ecosystem services. Renew. Agric. Food Syst. 2014, 29, 101-125.

45. McGranahan, D.A.; Brown, P.W.; Schulte, L.A.; Tyndall, J.C. A historical primer on the US farm bill: Supply management and conservation policy. J. Soil Water Conserv. 2013, 68, 67A-73A.

46. Stuart, D.; Gillon, S. Scaling up to address new challenges to conservation on US farmland. Land Use Policy 2013, 31, 223-236.

47. Atwell, R.C.; Schulte, L.A.; Westphal, L.M. Tweak, adapt, or transform: Policy scenarios in response to emerging bioenergy markets in the US Corn Belt. Ecol. Soc. 2011, 16, 10.

48. Joubert, E. The development of wildlife utilization in South West Africa. J. S. Afr. Wildl. Manag. Assoc. 1974, 4, 35-42.

49. Von Wietersheim, A. Game farming. Afr. Wildl. 1988, 42, 69-75.

50. Joubert, E.; Brand, P.; Visagie, G. An appraisal of the utilization of game on private land in South West Africa. Madoqua 1983, 13, 197-219.

51. Barnes, J.I.; de Jager, J. Economic and financial incentives for wildlife use on private land in Namibia and the implications for policy. S. Afr. J. Wildl. Res. 1996, 26, 37-46.

52. McGranahan, D.A. Identifying ecological sustainability assessment factors for ecotourism and trophy hunting operations on private rangeland in Namibia. J. Sustain. Tour. 2011, 19, 115-131. 
53. McGranahan, D.A. Managing private, commercial rangelands for agricultural production and wildlife diversity in Namibia and Zambia. Biodivers. Conserv. 2008, 17, 1965-1977.

54. Lindsey, P.A.; Romañach, S.S.; Davies-Mostert, H.T. The importance of conservancies for enhancing the value of game ranch land for large mammal conservation in southern Africa. J. Zool. 2009, 277, 99-105.

55. Kreuter, U.; Peel, M.; Warner, E. Wildlife conservation and community-based natural resource management in Southern Africa's private nature reserves. Soc. Nat. Resour. 2010, 23, 507-524.

56. McGranahan, D.; Kirkman, K. Multifunctional rangeland in Southern Africa: Managing for production, conservation, and resilience with fire and grazing. Land 2013, 2, 176-193.

57. Torquebiau, E.; Cholet, N.; Ferguson, W.; Letourmy, P. Designing an index to reveal the potential of multipurpose landscapes in Southern Africa. Land 2013, 2, 705-725.

58. Whittaker, R.J.; Willis, K.J.; Field, R. Scale and species richness: Towards a general, hierarchical theory of species diversity. J. Biogeogr. 2001, 28, 453-470.

59. Díaz, S.; Cabido, M. Vive la difference: Plant functional diversity matters to ecosystem processes. Trends Ecol. Evol. 2001, 16, 646-655.

60. Petchey, O.L.; Gaston, K.J. Functional diversity: Back to basics and looking forward. Ecol. Lett. 2006, 9, 741-758.

61. Kindscher, K.; Wells, P.V. Prairie plant guilds: A multivariate analysis of prairie species based on ecological and morphological traits. Vegetatio 1995, 117, 29-50.

62. Brown, C.S. Are functional guilds more realistic management units than individual species for restoration? Weed Technol. 2004, 18, 1566-1571.

63. De Bello, F.; Carmona, C.P.; Mason, N.W.H.; Sebastià, M.-T.; Lepš, J. Which trait dissimilarity for functional diversity: Trait means or trait overlap? J. Veg. Sci. 2013, 24, 807-819.

64. Elmqvist, T.; Folke, C.; Nyström, M.; Peterson, G.; Bengtsson, J.; Walker, B.; Norberg, J. Response diversity, ecosystem change, and resilience. Front. Ecol. Environ. 2003, 1, 488-494.

65. Mori, A.S.; Furukawa, T.; Sasaki, T. Response diversity determines the resilience of ecosystems to environmental change. Biol. Rev. 2013, 88, 349-364.

66. Chillo, V.; Anand, M.; Ojeda, R.A. Assessing the use of functional diversity as a measure of ecological resilience in arid rangelands. Ecosystems 2011, 14, 1168-1177.

67. Walker, B.H. Biodiversity and ecological redundancy. Conserv. Biol. 1992, 6, 18-23.

68. Hart, R. A natural ecosystem analog approach to the design of a successional crop system for tropical forest environments. Biotropica 1980, 12, 73-82.

69. Altieri, M.A. The ecological role of biodiversity in agroecosystems. Agric. Ecosyst. Environ. 1999, 74, 19-31.

70. Loreau, M.; Naeem, S.; Inchausti, P.; Bengtsson, J.; Grime, J.; Hector, A.; Hooper, D.; Huston, M.; Raffaelli, D.; Schmid, B. Biodiversity and ecosystem functioning: Current knowledge and future challenges. Science 2001, 294, 804-808.

71. Hooper, D.U.; Chapin, F.S., III; Ewel, J.J.; Hector, A.; Inchausti, P.; Lavorel, S.; Lawton, J.H.; Lodge, D.M.; Loreau, M.; Naeem, S.; et al. Effects of biodiversity on ecosystem functioning: A consensus of current knowledge. Ecol. Monogr. 2005, 75, 3-35.

72. Quijas, S.; Schmid, B.; Balvanera, P. Plant diversity enhances provision of ecosystem services: A new synthesis. Basic Appl. Ecol. 2010, 11, 582-593. 
73. Cardinale, B.J.; Matulich, K.L.; Hooper, D.U.; Byrnes, J.E.; Duffy, E.; Gamfeldt, L.; Balvanera, P.; O'Connor, M.I.; Gonzalez, A. The functional role of producer diversity in ecosystems. Am. J. Bot. 2011, 98, 572-592.

74. Hooper, D.U.; Solan, M.; Symstad, A.; Diaz, S.; Gessner, M.O.; Buchmann, N.; Degrange, V.; Grime, P.; Hulot, F.; Mermillod-Blondin, F.; et al. Species diversity, functional diversity and ecosystem functioning. In Biodiversity and Ecosystem Functioning: Syntheses and Perspectives; Oxford University Press: Oxford, UK, 2002; pp. 195-208.

75. Hector, A.; Bagchi, R. Biodiversity and ecosystem multifunctionality. Nature 2007, 448, 188-190.

76. Isbell, F.; Calcagno, V.; Hector, A.; Connolly, J.; Harpole, W.S.; Reich, P.B.; Scherer-Lorenzen, M.; Schmid, B.; Tilman, D.; van Ruijven, J.; et al. High plant diversity is needed to maintain ecosystem services. Nature 2011, 477, 199-202.

77. Fridley, J. Resource availability dominates and alters the relationship between species diversity and ecosystem productivity in experimental plant communities. Oecologia 2002, 132, 271-277.

78. Wardle, D.; Bonner, K.; Nicholson, K. Biodiversity and plant litter: Experimental evidence which does not support the view that enhanced species richness improves ecosystem function. Oikos 1997, 79, 247-258.

79. Tilman, D.; Wedin, D.; Knops, J. Productivity and sustainability influenced by biodiversity in grassland ecosystems. Nature 1996, 379, 718-720.

80. Naeem, S.; Thompson, L.J.; Lawler, S.P.; Lawton, J.H.; Woodfin, R.M. Empirical evidence that declining species diversity may alter the performance of terrestrial ecosystems. Philos. Trans. R. Soc. B Biol. Sci. 1995, 347, 249-262.

81. Huston, M.A. Hidden treatments in ecological experiments: Re-evaluating the ecosystem function of biodiversity. Oecologia 1997, 110, 449-460.

82. Hector, A.; Bazeley-White, E.; Loreau, M.; Otway, S.; Schmid, B. Overyielding in grassland communities: Testing the sampling effect hypothesis with replicated biodiversity experiments. Ecol. Lett. 2002, 5, 502-511.

83. Aarssen, L.W. High productivity in grassland ecosystems: Effected by species diversity or productive species? Oikos 1997, 80, 183-184.

84. Tilman, D. Distinguishing between the effects of species diversity and species composition. Oikos 1997, 80, 185.

85. Loreau, M. Separating sampling and other effects in biodiversity experiments. Oikos 1998, $82,600-602$.

86. Cottingham, K.L.; Brown, B.L.; Lennon, J.T. Biodiversity may regulate the temporal variability of ecological systems. Ecol. Lett. 2001, 4, 72-85.

87. Loreau, M. Does functional redundancy exist? Oikos 2004, 104, 606-611.

88. Loreau, M.; Hector, A. Partitioning selection and complementarity in biodiversity experiments. Nature 2001, 412, 72-76.

89. Picasso, V.D.; Brummer, E.C.; Liebman, M.; Dixon, P.M.; Wilsey, B.J. Diverse perennial crop mixtures sustain higher productivity over time based on ecological complementarity. Renew. Agric. Food Syst. 2011, 26, 317-327. 
90. Cardinale, B.J.; Wright, J.P.; Cadotte, M.W.; Carroll, I.T.; Hector, A.; Srivastava, D.S.; Loreau, M.; Weis, J.J. Impacts of plant diversity on biomass production increase through time because of species complementarity. Proc. Natl. Acad. Sci. USA 2007, 104, 18123-18128.

91. Picasso, V.D.; Brummer, E.C.; Liebman, M.; Dixon, P.M.; Wilsey, B.J. Crop species diversity affects productivity and weed suppression in perennial polycultures under two management strategies. Crop Sci. 2008, 48, 331-342.

92. Bullock, J.M.; Pywell, R.F.; Burke, M.J.; Walker, K.J. Restoration of biodiversity enhances agricultural production. Ecol. Lett. 2001, 4, 185-189.

93. Bullock, J.M.; Pywell, R.F.; Walker, K.J. Long-term enhancement of agricultural production by restoration of biodiversity. J. Appl. Ecol. 2006, 44, 6-12.

94. Jelinski, N.A.; Kucharik, C.J.; Zedler, J.B. A test of diversity-productivity models in natural, degraded, and restored wet prairies. Restor. Ecol. 2011, 19, 186-193.

95. Fridley, J.D. The influence of species diversity on ecosystem productivity: How, where, and why? Oikos 2001, 93, 514-526.

96. Banik, P.; Midya, A.; Sarkar, B.K.; Ghose, S.S. Wheat and chickpea intercropping systems in an additive series experiment: Advantages and weed smothering. Eur. J. Agron. 2006, 24, 325-332.

97. Matson, P.A. Agricultural intensification and ecosystem properties. Science 1997, 277, 504-509.

98. Hurt, R.D. Problems of Plenty: The American Farmer in the Twentieth Century; Ivan R. Dee: Chicago, IL, USA, 2002.

99. Burton, R.J. Seeing through the "good farmer"s' eyes: Towards developing an understanding of the social symbolic value of "productivist" behavior. Sociol. Rural. 2004, 44, 195-215.

100. Kumar, B.M. Land use in Kerala: Changing scenarios and shifting paradigms. J. Trop. Agric. 2005, 42, 1-12.

101. MacLeod, C.J.; Moller, H. Intensification and diversification of New Zealand agriculture since 1960: An evaluation of current indicators of land use change. Agric. Ecosyst. Environ. 2006, $115,201-218$.

102. Hanson, J.D.; Liebig, M.A.; Merrill, S.D.; Tanaka, D.L.; Krupinsky, J.M.; Stott, D.E. Dynamic cropping systems: Increasing adaptability amid an uncertain future. Agron. J. 2007, 99, 939-943.

103. Singer, J.W.; Meek, D.W.; Sauer, T.J.; Prueger, J.H.; Hatfield, J.L. Variability of light interception and radiation use efficiency in maize and soybean. Field Crops Res. 2011, 121, 147-152.

104. Bremer, D.J.; Ham, J.M.; Owensby, C.E.; Knapp, A.K. Responses of soil respiration to clipping and grazing in a tallgrass prairie. J. Environ. Qual. 1998, 27, 1539-1548.

105. Heggenstaller, A.H.; Anex, R.P.; Liebman, M.; Sundberg, D.N.; Gibson, L.R. Productivity and nutrient dynamics in bioenergy double-cropping systems. Agron. J. 2008, 100, 1740-1748.

106. Heggenstaller, A.H.; Menalled, F.D.; Liebman, M.; Westerman, P.R. Seasonal patterns in post-dispersal seed predation of Abutilon theophrasti and Setaria faberi in three cropping systems. J. Appl. Ecol. 2006, 43, 999-1010.

107. Williams, C.L.; Liebman, M.; Westerman, P.R.; Borza, J.; Sundberg, D.; Danielson, B. Over-winter predation of Abutilon theophrasti and Setaria faberi seeds in arable land. Weed Res. 2009, 49, 439-447. 
108. Liebman, M.; Helmers, M.J.; Schulte, L.A.; Chase, C.A. Using biodiversity to link agricultural productivity with environmental quality: Results from three field experiments in Iowa. Renew. Agric. Food Syst. 2013, 28, 115-128.

109. Liebman, M.; Gibson, L.R.; Sundberg, D.N.; Heggenstaller, A.H.; Westerman, P.R.; Chase, C.A.; Hartzler, R.G.; Menalled, F.D.; Davis, A.S.; Dixon, P.M. Agronomic and economic performance characteristics of conventional and low-external-input cropping systems in the central corn belt. Agron. J. 2008, 100, 600-610.

110. Gómez, R.; Liebman, M.; Sundberg, D.N.; Chase, C.A. Comparison of crop management strategies involving crop genotype and weed management practices in conventional and more diverse cropping systems. Renew. Agric. Food Syst. 2012, 28, 220-233.

111. Cruse, M.J.; Liebman, M.; Raman, D.R.; Wiedenhoeft, M.H. Fossil energy use in conventional and low-external-input cropping systems. Agron. J. 2010, 102, 934-941.

112. Davis, A.S.; Hill, J.D.; Chase, C.A.; Johanns, A.M.; Liebman, M. Increasing cropping system diversity balances productivity, profitability and environmental health. PLoS One 2012, 7, e47149.

113. Heggenstaller, A.H.; Liebman, M.; Anex, R.P. Growth analysis of biomass production in sole-crop and double-crop corn systems. Crop Sci. 2009, 49, 2215-2224.

114. Cox, T.S.; Glover, J.D.; van Tassel, D.L.; Cox, C.M.; DeHaan, L.R. Prospects for developing perennial grain crops. BioScience 2006, 56, 649-659.

115. Cox, T.S.; van Tassel, D.L.; Cox, C.M.; DeHaan, L.R. Progress in breeding perennial grains. Crop Pasture Sci. 2010, 61, 513-521.

116. Glover, J.D.; Reganold, J.P.; Bell, L.W.; Borevitz, J.; Brummer, E.C.; Buckler, E.S.; Cox, C.M.; Cox, T.S.; Crews, T.E.; Culman, S.W.; et al. Increased food and ecosystem security via perennial grains. Science 2010, 328, 1638-1639.

117. Richards, D.G. Economics and "Nature's Standard": Wes Jackson and the land institute. Rev. Radic. Polit. Econ. 2009, 41, 186-195.

118. Ives, A.R.; Carpenter, S.R. Stability and diversity of ecosystems. Science 2007, 317, 58-62.

119. Campbell, V.; Murphy, G.; Romanuk, T.N. Experimental design and the outcome and interpretation of diversity-stability relations. Oikos 2011, 120, 399-408.

120. Grimm, V.; Wissel, C. Babel, or the ecological stability discussions: An inventory and analysis of terminology and a guide for avoiding confusion. Oecologia 1997, 109, 323-334.

121. King, A.W.; Pimm, S.L. Complexity, diversity, and stability: A reconciliation of theoretical and empirical results. Am. Nat. 1983, 122, 229-239.

122. Caldeira, M.C.; Hector, A.; Loreau, M.; Pereira, J.S. Species richness, temporal variability and resistance of biomass production in a Mediterranean grassland. Oikos 2005, 110, 115-123.

123. Doak, D.F.; Bigger, D.; Harding, E.K.; Marvier, M.A.; O’Malley, R.E.; Thomson, D. The statistical inevitability of stability - diversity relationships in community ecology. Am. Nat. 1998, 151, 264-276.

124. Tilman, D.; Lehman, C.L.; Bristow, C.E. Diversity-stability relationships: Statistical inevitability or ecological consequence? Am. Nat. 1998, 151, 277-282.

125. Thibaut, L.M.; Connolly, S.R. Understanding diversity-stability relationships: Towards a unified model of portfolio effects. Ecol. Lett. 2013, 16, 140-150. 
126. Spehn, E.; Hector, A.; Joshi, J.; Scherer-Lorenzen, M.; Schmid, B.; Bazeley-White, E.; Beierkuhnlein, C.; Caldeira, M.; Diemer, M.; Dimitrakopoulos, P. Ecosystem effects of biodiversity manipulations in European grasslands. Ecol. Monogr. 2005, 75, 37-63.

127. Tilman, D.; Reich, P.B.; Knops, J.M. Biodiversity and ecosystem stability in a decade-long grassland experiment. Nature 2006, 441, 629-632.

128. Bai, Y.; Han, X.; Wu, J.; Chen, Z.; Li, L. Ecosystem stability and compensatory effects in the Inner Mongolia grassland. Nature 2004, 431, 181-184.

129. Hector, A.; Hautier, Y.; Saner, P.; Wacker, L.; Bagchi, R.; Joshi, J.; Scherer-Lorenzen, M.; Spehn, E.M.; Bazeley-White, E.; Weilenmann, M. General stabilizing effects of plant diversity on grassland productivity through population asynchrony and overyielding. Ecology 2010, 91, 2213-2220.

130. Joner, F.; Specht, G.; Müller, S.C.; Pillar, V.D. Functional redundancy in a clipping experiment on grassland plant communities. Oikos 2011, 120, 1420-1426.

131. Pillar, V.D.; Blanco, C.C.; Müller, S.C.; Sosinski, E.E.; Joner, F.; Duarte, L.D.S. Functional redundancy and stability in plant communities. J. Veg. Sci. 2013, 24, 963-974.

132. Deak, A.; Hall, M.H.; Sanderson, M.A.; Rotz, A.; Corson, M. Whole-farm evaluation of forage mixtures and grazing strategies. Agron. J. 2010, 102, 1201-1209.

133. Loreau, M.; de Mazancourt, C. Species synchrony and its drivers: Neutral and nonneutral community dynamics in fluctuating environments. Am. Nat. 2008, 172, E48-E66.

134. Roscher, C.; Weigelt, A.; Proulx, R.; Marquard, E.; Schumacher, J.; Weisser, W.W.; Schmid, B. Identifying population- and community-level mechanisms of diversity-stability relationships in experimental grasslands: Diversity-stability relationships. J. Ecol. 2011, 99, 1460-1469.

135. Wilsey, B.J.; Potvin, C. Biodiversity and ecosystem functioning: Importance of species evenness in an old field. Ecology 2000, 81, 887-892.

136. Wilsey, B.J.; Polley, H.W. Realistically low species evenness does not alter grassland species-richness-productivity relationships. Ecology 2004, 85, 2693-2700.

137. Hillebrand, H.; Bennett, D.M.; Cadotte, M.W. Consequences of dominance: A review of evenness effects on local and regional ecosystem processes. Ecology 2008, 89, 1510-1520.

138. Jarchow, M.E.; Liebman, M.; Rawat, V.; Anex, R.P. Functional group and fertilization affect the composition and bioenergy yields of prairie plants. GCB Bioenergy 2012, 4, 671-679.

139. Jarchow, M.E.; Liebman, M. Nutrient enrichment reduces complementarity and increases priority effects in prairies managed for bioenergy. Biomass Bioenergy 2012, 36, 381-389.

140. Biondini, M. Plant diversity, production, stability, and susceptibility to invasion in restored northern tall grass prairies (United States). Restor. Ecol. 2007, 15, 77-87.

141. Jarchow, M.E.; Liebman, M. Nitrogen fertilization increases diversity and productivity of prairie communities used for bioenergy. GCB Bioenergy 2013, 5, 281-289.

142. Biondini, M.E.; Norland, J.E.; Grygiel, C.E. Plant richness-biomass relationships in restored northern Great Plains grasslands (USA). Int. J. Ecol. 2011, 2011, 1-13.

143. Yang, Z.; van Ruijven, J.; Du, G. The effects of long-term fertilization on the temporal stability of alpine meadow communities. Plant Soil 2011, 345, 315-324.

144. Polley, H.W.; Wilsey, B.J.; Derner, J.D. Dominant species constrain effects of species diversity on temporal variability in biomass production of tallgrass prairie. Oikos 2007, 116, 2044-2052. 
145. Sanderson, M.A. Stability of production and plant species diversity in managed grasslands: A retrospective study. Basic Appl. Ecol. 2010, 11, 216-224.

146. Deak, A.; Hall, M.H.; Sanderson, M.A.; Archibald, D.D. Production and nutritive value of grazed simple and complex forage mixtures. Agron. J. 2007, 99, 814-821.

147. Lovell, S.T.; Mendez, V.E.; Erickson, D.L.; Nathan, C.; DeSantis, S. Extent, pattern, and multifunctionality of treed habitats on farms in Vermont, USA. Agrofor. Syst. 2010, 80, 153-171.

148. Rosset, P.M.; Altieri, M.A. Agroecology versus input substitution: A fundamental contradiction of sustainable agriculture. Soc. Nat. Resour. 1997, 10, 283-295.

149. Lewis, W.J.; van Lenteren, J.C.; Phatak, S.C.; Tumlinson, J.H. A total system approach to sustainable pest management. Proc. Natl. Acad. Sci. USA 1997, 94, 12243-12248.

150. Altieri, M. Biodiversity and Pest Management in Agroecosystems; Hawthorn Press: New York, NY, USA, 1994.

151. Macfadyen, S.; Bohan, D.A. Crop domestication and the disruption of species interactions. Basic Appl. Ecol. 2010, 11, 116-125.

152. Steingröver, E.G.; Geertsema, W.; Wingerden, W.K.R.E. Designing agricultural landscapes for natural pest control: A transdisciplinary approach in the Hoeksche Waard (The Netherlands). Landsc. Ecol. 2010, 25, 825-838.

153. Shackelford, G.; Steward, P.R.; Benton, T.G.; Kunin, W.E.; Potts, S.G.; Biesmeijer, J.C.; Sait, S.M. Comparison of pollinators and natural enemies: A meta-analysis of landscape and local effects on abundance and richness in crops: Comparison of pollinators and natural enemies. Biol. Rev. 2013, 88, 1002-1021.

154. Root, R.B. Organization of a plant-arthropod association in simple and diverse habitats: The fauna of collards (Brassica oleracea). Ecol. Monogr. 1973, 43, 95-124.

155. Landis, D.A.; Wratten, S.D.; Gurr, G.M. Habitat management to conserve natural enemies of arthropod pests in agriculture. Annu. Rev. Entomol. 2000, 45, 175-201.

156. Kromp, B. Carabid beetles in sustainable agriculture: A review on pest control efficacy, cultivation impacts and enhancement. Agric. Ecosyst. Environ. 1999, 74, 187-228.

157. Varchola, J.M.; Dunn, J.P. Changes in ground beetle (Coleoptera: Carabidae) assemblages in farming systems bordered by complex or simple roadside vegetation. Agric. Ecosyst. Environ. 1999, 73, 41-49.

158. Woodcock, B.A.; Potts, S.G.; Pilgrim, E.; Ramsay, A.J.; Tscheulin, T.; Parkinson, A.; Smith, R.E.N.; Gundrey, A.L.; Brown, V.K.; Tallowin, J.R. The potential of grass field margin management for enhancing beetle diversity in intensive livestock farms: Field margins and beetle diversity. J. Appl. Ecol. 2006, 44, 60-69.

159. Symondson, W.; Sunderland, K.; Greenstone, M. Can generalist predators be effective biocontrol agents? Annu. Rev. Entomol. 2002, 47, 561-594.

160. Nyffeler, M.; Sunderland, K.D. Composition, abundance and pest control potential of spider communities in agroecosystems: A comparison of European and US studies. Agric. Ecosyst. Environ. 2003, 95, 579-612.

161. Ghazoul, J. Challenges to the uptake of the ecosystem service rationale for conservation. Conserv. Biol. 2007, 21, 1651-1652. 
162. Buhler, D.D.; Liebman, M.; Obrycki, J.J. Theoretical and practical challenges to an IPM approach to weed management. Weed Sci. 2009, 48, 274-280.

163. Goodell, P.B. Fifty years of the integrated control concept: The role of landscape ecology in IPM in San Joaquin Valley cotton. Pest Manag. Sci. 2009, 65, 1293-1297.

164. Naranjo, S.E.; Ellsworth, P.C. Fifty years of the integrated control concept: Moving the model and implementation forward in Arizona. Pest Manag. Sci. 2009, 65, 1267-1286.

165. Martin, E.A.; Reineking, B.; Seo, B.; Steffan-Dewenter, I. Natural enemy interactions constrain pest control in complex agricultural landscapes. Proc. Natl. Acad. Sci. USA 2013, 110, 5534-5539.

166. Tylianakis, J.M.; Romo, C.M. Natural enemy diversity and biological control: Making sense of the context-dependency. Basic Appl. Ecol. 2010, 11, 657-668.

167. Kremen, C.; Williams, N.M.; Thorp, R.W. Crop pollination from native bees at risk from agricultural intensification. Proc. Natl. Acad. Sci. USA 2002, 99, 16812-16816.

168. Potts, S.G.; Biesmeijer, J.C.; Kremen, C.; Neumann, P.; Schweiger, O.; Kunin, W.E. Global pollinator declines: Trends, impacts and drivers. Trends Ecol. Evol. 2010, 25, 345-353.

169. Potts, S.G.; Woodcock, B.A.; Roberts, S.P.M.; Tscheulin, T.; Pilgrim, E.S.; Brown, V.K.; Tallowin, J.R. Enhancing pollinator biodiversity in intensive grasslands. J. Appl. Ecol. 2009, 46, 369-379.

170. Carvalheiro, L.G.; Seymour, C.L.; Nicolson, S.W.; Veldtman, R. Creating patches of native flowers facilitates crop pollination in large agricultural fields: Mango as a case study. J. Appl. Ecol. 2012, 49, 1373-1383.

171. Carvalheiro, L.G.; Veldtman, R.; Shenkute, A.G.; Tesfay, G.B.; Pirk, C.W.W.; Donaldson, J.S.; Nicolson, S.W. Natural and within-farmland biodiversity enhances crop productivity. Ecol. Lett. 2011, 14, 251-259.

172. Garibaldi, L.A.; Steffan-Dewenter, I.; Kremen, C.; Morales, J.M.; Bommarco, R.; Cunningham, S.A.; Carvalheiro, L.G.; Chacoff, N.P.; Dudenhöffer, J.H.; Greenleaf, S.S.; et al. Stability of pollination services decreases with isolation from natural areas despite honey bee visits: Habitat isolation and pollination stability. Ecol. Lett. 2011, 14, 1062-1072.

173. Haaland, C.; Naisbit, R.E.; Bersier, L.-F. Sown wildflower strips for insect conservation: A review: Wildflower strips for insect conservation. Insect Conserv. Divers. 2011, 4, 60-80.

174. MacDonald, A.L. Blurring the Lines between Production and Conservation Lands: Bird Use of Prairie Strips in Rowcropped Landscapes. Master's Thesis, Iowa State University, Ames, IA, USA, 2012.

175. Korpela, E.-L.; Hyvönen, T.; Lindgren, S.; Kuussaari, M. Can pollination services, species diversity and conservation be simultaneously promoted by sown wildflower strips on farmland? Agric. Ecosyst. Environ. 2013, 179, 18-24.

176. Moranz, R.A.; Fuhlendorf, S.D.; Engle, D.M. Making sense of a prairie butterfly paradox: The effects of grazing, time since fire, and sampling period on regal fritillary abundance. Biol. Conserv. 2014, 173, 32-41.

177. Sulc, R.M.; Tracy, B.F. Integrated crop-livestock systems in the U.S. Corn Belt. Agron. J. 2007, 99, 335-345.

178. Sulc, R.M.; Franzluebbers, A.J. Exploring integrated crop-livestock systems in different ecoregions of the United States. Eur. J. Agron. 2014, 57, 21-30. 
179. Duffy, J.E.; Cardinale, B.J.; France, K.E.; McIntyre, P.B.; Thébault, E.; Loreau, M. The functional role of biodiversity in ecosystems: Incorporating trophic complexity. Ecol. Lett. 2007, 10, 522-538.

180. Leopold, A. A biotic view of land. J. For. 1939, 37, 727-730.

181. Russelle, M.P.; Entz, M.H.; Franzluebbers, A.J. Reconsidering integrated crop-livestock systems in North America. Agron. J. 2007, 99, 325-334.

182. Rotz, C.A.; Taube, F.; Russelle, M.P.; Oenema, J.; Sanderson, M.A.; Wachendorf, M. Whole-farm perspectives of nutrient flows in grassland agriculture. Crop Sci. 2005, 45, 2139-2159.

183. Stark, C.H.; Richards, K.G. The continuing challenge of nitrogen loss to the environment: Environmental consequences and mitigation strategies. Dyn. Soil Dyn. Plant 2008, 2, 41-55.

184. Goulding, K.; Jarvis, S.; Whitmore, A. Optimizing nutrient management for farm systems. Philos. Trans. R. Soc. B Biol. Sci. 2008, 363, 667-680.

185. Petersen, S.O.; Sommer, S.G.; Béline, F.; Burton, C.; Dach, J.; Dourmad, J.Y.; Leip, A.; Misselbrook, T.; Nicholson, F.; Poulsen, H.D.; et al. Recycling of livestock manure in a whole-farm perspective. Livest. Sci. 2007, 112, 180-191.

186. Herrero, M.; Thornton, P.K.; Gerber, P.; Reid, R.S. Livestock, livelihoods and the environment: Understanding the trade-offs. Curr. Opin. Environ. Sustain. 2009, 1, 111-120.

187. Steinfeld, H.; Gerber, P.; Wassenaar, T.; Castel, V.; de Haan, C. Livestock's Long Shadow: Environmental Issues and Options; Food \& Agriculture Organization: Rome, Italy, 2006.

188. Pitesky, M.E.; Stackhouse, K.R.; Mitloehner, F.M. Clearing the air. Adv. Agron. 2009, 103, 1-40.

189. Gerber, P.J.; Vellinga, T.V.; Steinfeld, H. Issues and options in addressing the environmental consequences of livestock sector's growth. Meat Sci. 2010, 84, 244-247.

190. Pelletier, N.; Tyedmers, P. Forecasting potential global environmental costs of livestock production 2000-2050. Proc. Natl. Acad. Sci. USA 2010, 107, 18371-18374.

191. McAlpine, C.A.; Etter, A.; Fearnside, P.M.; Seabrook, L.; Laurance, W.F. Increasing world consumption of beef as a driver of regional and global change: A call for policy action based on evidence from Queensland (Australia), Colombia and Brazil. Glob. Environ. Chang. 2009, $19,21-33$.

192. Capper, J.L. The environmental impact of beef production in the United States: 1977 compared with 2007. J. Anim. Sci. 2011, 89, 4249-4261.

193. Capper, J.L.; Bauman, D.E. The role of productivity in improving the environmental sustainability of ruminant production systems. Annu. Rev. Anim. Biosci. 2013, 1, 469-489.

194. Steinfeld, H.; Gerber, P. Livestock production and the global environment: Consume less or produce better? Proc. Natl. Acad. Sci. USA 2010, 107, 18237-18238.

195. Wirsenius, S.; Azar, C.; Berndes, G. How much land is needed for global food production under scenarios of dietary changes and livestock productivity increases in 2030? Agric. Syst. 2010, $103,621-638$.

196. Janzen, H.H. What place for livestock on a re-greening earth? Anim. Feed Sci. Technol. 2011, 166-167, 783-796.

197. Barbieri, C.; Mahoney, E. Why is diversification an attractive farm adjustment strategy? Insights from Texas farmers and ranchers. J. Rural Stud. 2009, 25, 58-66. 
198. Cumming, G.S.; Cumming, D.H.; Redman, C.L. Scale mismatches in social-ecological systems: Causes, consequences, and solutions. Ecol. Soc. 2006, 11, 14.

199. Pelosi, C.; Goulard, M.; Balent, G. The spatial scale mismatch between ecological processes and agricultural management: Do difficulties come from underlying theoretical frameworks? Agric. Ecosyst. Environ. 2010, 139, 455-462.

200. Turner, M.G. Landscape ecology: What is the state of the science? Annu. Rev. Ecol. Syst. 2005, 36, 319-344.

201. Dale, V.H.; Kline, K.L.; Kaffka, S.R.; Langeveld, J.W.A. A landscape perspective on sustainability of agricultural systems. Landsc. Ecol. 2013, 28, 1111-1123.

202. Matthews, R.; Selman, P. Landscape as a focus for integrating human and environmental processes. J. Agric. Econ. 2006, 57, 199-212.

203. Otte, A.; Simmering, D.; Wolters, V. Biodiversity at the landscape level: Recent concepts and perspectives for multifunctional land use. Landsc. Ecol. 2007, 22, 639-642.

204. Scherr, S.J.; McNeely, J.A. Biodiversity conservation and agricultural sustainability: Towards a new paradigm of "ecoagriculture" landscapes. Philos. Trans. R. Soc. Lond. B. Biol. Sci. 2008, $363,477-494$.

205. Lovell, S.T.; Johnston, D.M. Designing landscapes for performance based on emerging principles in landscape ecology. Ecol. Soc. 2009, 14, 44.

206. Wilson, T.S.; Sleeter, B.M.; Sleeter, R.R.; Soulard, C.E. Land-use threats and protected areas: A scenario-based, landscape level approach. Land 2014, 3, 362-389.

207. Kotliar, N.B.; Wiens, J.A. Multiple scales of patchiness and patch structure: A hierarchical framework for the study of heterogeneity. Oikos 1990, 59, 253-260.

208. Senft, R.L.; Coughenour, M.B.; Bailey, D.W.; Rittenhouse, L.R.; Sala, O.E.; Swift, D.M. Large herbivore foraging and ecological hierarchies. BioScience 1987, 37, 789-799.

209. Pickett, S.R.A.; Siriwardena, G.M. The relationship between multi-scale habitat heterogeneity and farmland bird abundance. Ecography 2011, 34, 955-969.

210. Katayama, N.; Amano, T.; Naoe, S.; Yamakita, T.; Komatsu, I.; Takagawa, S.; Sato, N.; Ueta, M.; Miyashita, T. Landscape heterogeneity-biodiversity relationship: Effect of range size. PLoS One 2014, 9, e93359.

211. MacArthur, R.H.; Wilson, E.O. An equilibrium theory of insular zoogeography. Evolution 1963, $17,373-387$.

212. Ricketts, T.H. The matrix matters: Effective isolation in fragmented landscapes. Am. Nat. 2001, 158, 87-99.

213. Ricketts, T.H.; Daily, G.C.; Ehrlich, P.R.; Fay, J.P. Countryside biogeography of moths in a fragmented landscape: Biodiversity in native and agricultural habitat. Conserv. Biol. 2001, $15,378-388$.

214. Fischer, J.; Lindenmayer, D.B.; Manning, A.D. Biodiversity, ecosystem function, and resilience: Ten guiding principles for commodity production landscapes. Front. Ecol. Environ. 2006, 4, 80-86.

215. Fischer, J.; Lindenmayer, D.B.; Fazey, I. Appreciating ecological complexity: Habitat contours as a conceptual landscape model. Conserv. Biol. 2004, 18, 1245-1253. 
216. Dutton, A.; Edwards-Jones, G.; Strachan, R.; Macdonald, D.W. Ecological and social challenges to biodiversity conservation on farmland: Reconnecting habitats on a landscape scale. Mamm. Rev. 2008, 38, 205-219.

217. Senft, R.L.; Rittenhouse, L.R.; Woodmansee, R.G. Factors influencing patterns of cattle grazing behavior on shortgrass steppe. J. Range Manag. 1985, 38, 82-87.

218. Bailey, D.W.; Gross, J.E.; Laca, E.A.; Rittenhouse, L.R.; Coughenour, M.B.; Swift, D.M.; Sims, P.L. Mechanisms that result in large herbivore grazing distribution patterns. J. Range Manag. 1996, 49, 386-400.

219. Fuhlendorf, S.D.; Smeins, F.E. The influence of soil depth on plant species response to grazing within a semi-arid savanna. Plant Ecol. 1998, 138, 89-96.

220. Fuhlendorf, S.D.; Smeins, F.E. Scaling effects of grazing in a semi-arid grassland. J. Veg. Sci. 1999, 10, 731-738.

221. Norton, B.E.; Barnes, M.; Teague, R. Grazing management can improve livestock distribution: Increasing accessible forage and effective grazing capacity. Rangelands 2013, 35, 45-51.

222. Fuhlendorf, S.D.; Engle, D.M. Restoring heterogeneity on rangelands: Ecosystem management based on evolutionary grazing patterns. BioScience 2001, 51, 625-632.

223. Sensenig, R.L.; Demment, M.W.; Laca, E.A. Allometric scaling predicts preferences for burned patches in a guild of East African grazers. Ecology 2010, 91, 2898-2907.

224. Allred, B.W.; Fuhlendorf, S.D.; Engle, D.M.; Elmore, R.D. Ungulate preference for burned patches reveals strength of fire-grazing interaction. Ecol. Evol. 2011, 1, 132-144.

225. Fuhlendorf, S.D.; Engle, D.M. Application of the fire-grazing interaction to restore a shifting mosaic on tallgrass prairie. J. Appl. Ecol. 2004, 41, 604-614.

226. Fuhlendorf, S.D.; Harrell, W.C.; Engle, D.M.; Hamilton, R.G.; Davis, C.A.; Leslie, D.M., Jr. Should heterogeneity be the basis for conservation? Grassland bird response to fire and grazing. Ecol. Appl. 2006, 16, 1706-1716.

227. Coppedge, B.; Fuhlendorf, S.D.; Harrell, W.C.; Engle, D.M. Avian community response to vegetation and structural features in grasslands managed with fire and grazing. Biol. Conserv. 2008, 141, 1196-1203.

228. Engle, D.M.; Fuhlendorf, S.D.; Roper, A.; Leslie, D.M., Jr. Invertebrate community response to a shifting mosaic of habitat. Rangel. Ecol. Manag. 2008, 61, 55-62.

229. Doxon, E.D.; Davis, C.A.; Fuhlendorf, S.D.; Winter, S.L. Aboveground macroinvertebrate diversity and abundance in sand sagebrush prairie managed with the use of pyric herbivory. Rangel. Ecol. Manag. 2011, 64, 394-403.

230. Fuhlendorf, S.D.; Engle, D.M.; Kerby, J.; Hamilton, R. Pyric herbivory: Rewilding landscapes through the recoupling of fire and grazing. Conserv. Biol. 2009, 23, 588-598.

231. McGranahan, D.A.; Engle, D.M.; Fuhlendorf, S.D.; Winter, S.J.; Miller, J.R.; Debinski, D.M. Spatial heterogeneity across five rangelands managed with pyric-herbivory. J. Appl. Ecol. 2012, 49, 903-910.

232. Tews, J.; Brose, U.; Grimm, V.; Tielbörger, K.; Wichmann, M.C.; Schwager, M.; Jeltsch, F. Animal species diversity driven by habitat heterogeneity/diversity: The importance of keystone structures. J. Biogeogr. 2004, 31, 79-92. 
233. McGranahan, D.A.; Engle, D.M.; Fuhlendorf, S.D.; Winter, S.L.; Miller, J.R.; Debinski, D.M. Inconsistent outcomes of heterogeneity-based management underscore importance of matching evaluation to conservation objectives. Environ. Sci. Policy 2013, 31, 53-60.

234. Toombs, T.P.; Derner, J.D.; Augustine, D.J.; Krueger, B.; Gallagher, S. Managing for biodiversity and livestock. Rangelands 2010, 32, 10-15.

235. Fuhlendorf, S.D.; Engle, D.M.; Elmore, R.D.; Limb, R.F.; Bidwell, T.G. Conservation of pattern and process: Developing an alternative paradigm of rangeland management. Rangel. Ecol. Manag. 2012, $65,579-589$.

236. Derner, J.D.; Lauenroth, W.K.; Stapp, P.; Augustine, D.J. Livestock as ecosystem engineers for grassland bird habitat in the western Great Plains of North America. Rangel. Ecol. Manag. 2009, 62, 111-118.

237. Allred, B.W.; Fuhlendorf, S.D.; Hovick, T.J.; Dwayne Elmore, R.; Engle, D.M.; Joern, A. Conservation implications of native and introduced ungulates in a changing climate. Glob. Chang. Biol. 2013, 19, 1875-1883.

238. Limb, R.F.; Fuhlendorf, S.D.; Engle, D.M.; Weir, J.R.; Elmore, R.D.; Bidwell, T.G. Pyric-herbivory and cattle performance in grassland ecosystems. Rangel. Ecol. Manag. 2011, 64, 659-663.

239. Scasta, J.D.; Engle, D.M.; Talley, J.L.; Weir, J.R.; Stansberry, J.C.; Fuhlendorf, S.D.; Harr, R.N. Pyric-herbivory to manage horn flies (Diptera: Muscidae) on cattle. Southwest. Entomol. 2012, 37, 325-334.

240. Owen-Smith, N. Functional heterogeneity in resources within landscapes and herbivore population dynamics. Landsc. Ecol. 2004, 19, 761-771.

241. Fynn, R.W.S. Functional resource heterogeneity increases livestock and rangeland productivity. Rangel. Ecol. Manag. 2012, 65, 319-329.

242. Allred, B.W.; Scasta, J.D.; Hovick, T.J.; Fuhlendorf, S.D.; Hamilton, R.G. Spatial heterogeneity stabilizes livestock productivity in a changing climate. Agric. Ecosyst. Environ. 2014, 193, 37-41.

243. McGranahan, D.A.; Henderson, C.B.; Hill, J.S.; Raicovich, G.M.; Wilson, W.N.; Smith, C.K. Patch burning improves forage quality and creates grassbank in old-field pasture: Results of a demonstration trial. Southeast. Nat. 2014, 13, 200-207.

244. Tilman, D.; Socolow, R.; Foley, J.A.; Hill, J.; Larson, E.; Lynd, L.; Pacala, S.; Reilly, J.; Searchinger, T.; Somerville, C. Beneficial biofuels-The food, energy, and environment trilemma. Science 2009, 325, 270-271.

245. Wilhelm, W.W.; Johnson, J.M.F.; Karlen, D.L.; Lightle, D.T. Corn stover to sustain soil organic carbon further constrains biomass supply. Agron. J. 2007, 99, 1665-1667.

246. Piñeiro, G.; Jobbágy, E.G.; Baker, J.; Murray, B.C.; Jackson, R.B. Set-asides can be better climate investment than corn ethanol. Ecol. Appl. 2009, 19, 277-282.

247. Fargione, J.E.; Cooper, T.R.; Flaspohler, D.J.; Hill, J.; Lehman, C.; Tilman, D.; McCoy, T.; McLeod, S.; Nelson, E.J.; Oberhauser, K.S. Bioenergy and wildlife: Threats and opportunities for grassland conservation. BioScience 2009, 59, 767-777.

248. Altieri, M.A. The Ecological impacts of large-scale agrofuel monoculture production systems in the Americas. Bull. Sci. Technol. Soc. 2009, 29, 236-244. 
249. Wiens, J.; Fargione, J.; Hill, J. Biofuels and biodiversity. Ecol. Appl. 2011, 21, 1085-1095.

250. Fargione, J.E.; Plevin, R.J.; Hill, J.D. The ecological impact of biofuels. Annu. Rev. Ecol. Evol. Syst. 2010, 41, 351-377.

251. Heaton, E.A.; Schulte, L.A.; Berti, M.; Langeveld, H.; Zegada-Lizarazu, W.; Parrish, D.; Monti, A. Managing a second-generation crop portfolio through sustainable intensification: Examples from the USA and the EU. Biofuels Bioprod. Biorefining 2013, 7, 702-714.

252. Jarchow, M.E.; Liebman, M.; Dhungel, S.; Dietzel, R.; Sundberg, D.; Anex, R.P.; Thompson, M.L.; Chua, T. Trade-offs among agronomic, energetic, and environmental performance characteristics of corn and prairie bioenergy cropping systems. GCB Bioenergy 2014, doi:10.1111/gcbb.12096.

253. Daigh, A.L.; Zhou, X.; Helmers, M.J.; Pederson, C.H.; Ewing, R.; Horton, R. Subsurface drainage flow and soil water dynamics of reconstructed prairies and corn rotations for biofuel production. Vadose Zone J. 2014, 13, doi:10.2136/vzj2013.10.0177.

254. Jarchow, M.E.; Liebman, M. Maintaining multifunctionality as landscapes provide ecosystem services. Front. Ecol. Environ. 2011, 9, 262-262.

255. Tyndall, J.C.; Schulte, L.A.; Liebman, M.; Helmers, M. Field-level financial assessment of contour prairie strips for enhancement of environmental quality. Environ. Manag. 2013, 52, 736-747.

256. Schilling, K.E.; Drobney, P. Restoration of prairie hydrology at the watershed scale: Two decades of progress at Neal Smith National Wildlife Refuge, Iowa. Land 2014, 3, 206-238.

257. Hernandez-Santana, V.; Zhou, X.; Helmers, M.J.; Asbjornsen, H.; Kolka, R.; Tomer, M. Native prairie filter strips reduce runoff from hillslopes under annual row-crop systems in Iowa, USA. J. Hydrol. 2013, 477, 94-103.

258. Zhou, X.; Helmers, M.J.; Asbjornsen, H.; Kolka, R.; Tomer, M.D.; Cruse, R.M. Nutrient removal by prairie filter strips in agricultural landscapes. J. Soil Water Conserv. 2014, 69, 54-64.

259. Hirsh, S.M.; Mabry, C.M.; Schulte, L.A.; Liebman, M. Diversifying agricultural catchments by incorporating tallgrass prairie buffer strips. Ecol. Restor. 2013, 31, 201-211.

260. Robertson, G.P.; Swinton, S.M. Reconciling agricultural productivity and environmental integrity: A grand challenge for agriculture. Front. Ecol. Environ. 2005, 3, 38-46.

261. Cong, R.-G.; Smith, H.G.; Olsson, O.; Brady, M. Managing ecosystem services for agriculture: Will landscape-scale management pay? Ecol. Econ. 2014, 99, 53-62.

(C) 2014 by the authors; licensee MDPI, Basel, Switzerland. This article is an open access article distributed under the terms and conditions of the Creative Commons Attribution license (http://creativecommons.org/licenses/by/3.0/). 